Boban Stojanović ${ }^{1}$

University of Niš, Faculty of Economics
ORIGINAL SCIENTIFIC ARTICLE doi:10.5937/ekonomika1802023S

Received January, 22, 2018

Accepted: March, 01, 2018

\title{
STATE, INSTITUTIONAL INFRASTRUCTURE AND TRANSITION ENGINEERING IN REPUBLIC OF SERBIA
}

\begin{abstract}
Radical changes in the transition should enable the restructuring of the economy and financial markets, involvement in European and worldwide integration streams, influx of capital and creation of a favorable business environment. The creation of market infrastructure demands time and cannot, except in specific segments, be created by decrees. The implementation of changes in the economical and institutional environment has to be a sensibly channeled process. Apart from the reconstruction of the existing institutions, new institutions have to be created and substantial changes of their functioning have to be implemented. The underlying assumptions in the process of establishment of the goals and means of transforming the Serbian economy are the norms of a liberal market economy and the demands for an integral market and the universal action of market mechanisms. Thereby, a critical standpoint and selectiveness in the choice of methods for the creation of the transition, especially in the case of an installation of liberalism norms, must exist. The worldwide financial crisis points out the significant limitations of neoliberalism. The role of interventionism through state is more significant.
\end{abstract}

Key words: transition, institutions, market, state, interventionism, constructivism

JEL classification: D0, P20, H70

\section{ДРЖАВА, ИНСТИТУЦИОНАЛНА ИНФРАСТРУКТУРА И ТРАНЗИЦИОНИ ИНЖЕЊЕРИНГ У РЕПУБЛИЦИ СРБИЈИ}

\section{Апстракт}

Радикална промена коју подразумева транзииија треба да обезбеди реструктурирање привреде и финансијског тржситта, укључивање у европске и светске интеграционе токове, прилив капитала, стварање повољног амбијента за пословање. Изградња тржишне инфраструктуре захтева време и не може се, осим у појединим сегментима, успостављати декретима. Остваривағе неопходних измена привредно-системског и институционалног окружења мора бити свесно каналисан процес. Осим реконструкције постојећих, потребно је уводити нове институције и извриити обимне промене юиховог функиионисања. При конциипирању ичиљева и начина трансформисања привреде Србије полази се од норми либералне тржишне привреде и захтева за интегралним тржиштем и универзалним деловањем тржишног механизма.

\footnotetext{
${ }^{1}$ dr.boban.stojanovic@gmail.com
} 
При томе мора да постоји критички став и селективност у избору метода креирањ а транзиције, нарочито у случају “инсталирања" норми либерализма. Економска криза у свету указује на значајна ограничења меолиберализма. На сиену све израженије ступа интервенционизам у виду помоћи државе.

Кључне речи: институчије, тржиште, држава, интервенционизам, конструктивизам.

\section{Introduction}

The transition process involves the implementation of complex changes in the economy and society. It is present in all former socialist countries. After more than 25 years, conclusions about the content and effects of transition can be drawn. The comprehensiveness is different in different countries. The results of the undertaken transition actions are also different. Today we can talk about good performance and economic structures that successfully enter to the world economic trends, but also about the other economies that still can not reach the level of domestic product from the late eighties. The reasons for greater or less successful transition is not easily explained due to simultaneous effect of economic and non-economic factors on the pretransitional processes, as well as on the flow and content of the transition process.

One of the basic tasks of transition is to create more favorable environment for expressing individual preferences of the population and businesses and their alignment with collective preferences. In economic terms, this means that prerequisites should be created for the achievement of the target functions of businesses and consumers, which would lead to efficient business, both at the microeconomic level and at the national level.

The radical change that transition should involve provides: 1) the restructuring of the economy and the financial market, 2) inclusion in the European and global integration flows, 3) capital inflows, 4) creation of a favorable business environment. By implementing a comprehensive change of the economic and social system, preconditions for achieving the characteristics of contemporary societies - democracy, competence, competitiveness, innovativeness and inventiveness, a new entrepreneurial spirit are being created, In the domain of commitment for these goals, there is no doubt. There are dilemmas about the way and the speed of building new institutions of the market economy.

Building a market infrastructure requires time and can not, except in certain segments, be established by decrees. Also, building an integrated markets implies creating a favorable socio-economic environment. Realizing the necessary changes in the economic-system and institutional environment must be a deliberately controlled process. This process, as the transition process as a whole, is a combination of spontaneous and planned guidance with greater or less domination and the significance one of these two approaches, depending on the phase of transition.

Except the reconstruction of existing institutions, it is necessary to introduce new ones at the same time and to make extensive changes in their functioning. In conceiving the goals and way of transforming the economy, in theory and practice, it often starts from the norms of a liberal market economy and requests for an integral market and the universal functioning of a market mechanism with an informative, selective, allocative and distribution function.

Neoliberalist conceptions are based on the necessity of having the freedom of individual 
activities within the framework of institutions in the broadest sense (markets, laws, property rights, prevention of monopoly, etc.). Thereby, there must be a critical attitude and selectivity in choosing the methods of creating a transition, especially in the case of "installing" the norms of liberalism. The economic crisis in the world points out the significant restrictions of liberalism. On the scene, interventionism is more pronounced in the form of state assistance to even private companies and banks, but also significant interventions in the financial market. The market is becoming more and more regulated, not anarchic; regular, not gray. Market process control is applied based on the model of developed countries and countries in transition.

\section{Spontaneity and constructivism in the transition process}

If the free movement of the market mechanism, as a goal of transition, arises, attention is drawn to Hajek (1998) by his analysis of free order and constructivism. The free order implies respecting the rules that are independent of the intentions of individuals or interest groups. These general rules are based on tradition or customs. Individual market actors only adapt to environment parameters that are not subject to "violent" changes. Spontaneously established rules can not be changed neither by economic nor by any other interventions. Even it can be argued that interventionism is detrimental due to it represents a violation of the natural order. The state must ensure respect the norms necessary for the functioning of the spontaneous order.

At the beginning of the transition process in post-socialist economies, all preconditions for achieving a spontaneous order can not be created. The inherited institutional framework and the code conduct system of economic actors does not allow the functioning of a free market game. In these economies, therefore, there is not system of rules or institutions that meet the requirements of a spontaneous order. If there are not necessary preconditions, then they should be created. In other words, a new system of rules and institutions of a market economy should be established. Obviously, in this transition, there is a necessary discontinuity in the functioning of the economy and society.

In the case of the formation of completely new institutions, unknown ones for these economies, as well as the rules of conduct, it can also lead to a certain vacuum, which should quickly be filled in by the institutions of the market economy. In addition, constructivism in Hajek's sense is necessary because it is about designing the norms of a market economy to the reality which is burdened by the legacy of planned economic flows, the absence or insufficient representation of market economy institutions (capital markets, labor, "hard" budget constraints, etc.).

The results of the undertaken transition transitions are very different. In one group of countries, a fundamental, radical and relatively rapid reconstruction of the functioning of economic and social processes was carried out. In the second group of countries, declarative commitment for essential changes appears, but the foreseen effects are missing in the implementation, mostly due to the lack of synchronized and simultaneous interventions in all spheres and the insufficiently energetic break with the recurrences of the past. As a result of such a situation, a political and economic transition is being implemented (or implemented) in one group of countries, while asynchronous and more or less cosmetic changes in different segments of the economy and society occur in the other group of countries.

These differences in transition engineering and in the effects of the undertaken changes show that the fundamental reconstruction of the economy and society implies simultaneous 
deep political and economic transformation. An insight into the current results of transition in Serbia shows that significant reform activities have been undertaken, but there are not still desired results.

Clearly defining goals, means and holders of the process of economic and social changes, is a significant prerequisite for a successful transition. The instrumentarium for the change implementation must be adapted to the market economy and to a democratic society. In order to achieve the goals of transition, the institutional framework must be changed, and in certain segments it is necessary to build new institutions and to constitute new rules of conduct.

\section{The importance of changing existing and building new institutions in the transition process}

The differences in the success of transition in some countries can not be easily explained due to simultaneous effect of economic and non-economic factors. In order to achieve the transition objectives, all relevant parameters of this process should be taken into account. After reviewing the existing conditions, change of the institutional framework and the construction of new institutions and codes of conduct is approached. Building the institutional ambient that is supportive to implementation of desired reforms is the most important task of every transition process. In doing so, we should start from wider understanding of institutions as sets of formal and informal rules that determine social relations and through which legality in the interactions of individuals and social groups is expressed.

In the broadest context of neo-institutionalism, the development of a free order implies respect the rules that, independently of the intentions of actual individuals or interest groups, have been formed as a result of the historical processes of shaping social relations. Formed over a long period of time, such rules become the laws that are verified in the daily interactions of individuals, social groups and institutions. These general rules are based on tradition, customs, religion, culture. Since non-formal rules are expressed independently of the needs and demands of a particular social process, their effect on this process has a parametric character. As objectively given and immune to the influence of the willingness of individuals or groups, informal rules are not subject to "violent" changes. The state, therefore, must ensure respecting the norms necessary for the functioning of the spontaneous order and their evolutionary development.

Constructivism in Hajek's sense refers to the design the norms of a market economy into reality of the economies burdened by inherited economic structure, the absence or insufficient institutions of market economy. If spontaneous building of institutions of market economies would be realized, the process would require a long period of time.

Time is, however, one of the most deficient transition factors. Therefore, it seems quite rational to take over the solutions that have already been proven successful in the practice of developed market economies. Some economic analysts therefore have emphasized the benefits of the delayed transition reflected in the avoidance of mistakes made by creators in countries that had previously initiated this process. Of course, this was not possible in all cases. The downloaded or customized solutions should in any case lead to increasing the efficiency of using existing economic resources and creating a new economic structure with good performance. 
The spontaneous order continues to operate at the beginning of the transition process, but now combined with new formal rules. The inherited institutional framework and rules of conduct of economic actors did not allow the full realization of democracy and the manifestation of all market functions. In these economies, therefore, there is no system of rules or institutions that meet the requirements of the projected goals. If there are not yet prerequisites, then it should be created. In other words, a new system of rules and institutions of a market economy should be established. Obviously, in this transition, discontinuity in the models of the functioning of the economy and society necessarily occurs.

In the case of the formation of completely new, unknown institutions and rules of conduct in these economies, a vacuum may be occured, which of course must be quickly filled up with the institutions of the market economy. In doing so, the traditional issue of adapting foreign models to domestic conditions is posed. If this complex engineering is achieved in the field of normativism, there remains a huge problem of implementation in the real business environment.

\section{Market infrastructure and implementation of formal rules: previous experiences in Serbia}

There is a delicate mix of intent and spontaneity in system change. According to Klaus, there are three stages of transition. The first phase is characterized by constructivism. The second stage is the implementation of economic-systemic solutions and the concretization of global defining. In the third, final phase, the economic system begins to function in accordance with the defined goals and gradually adapt to the post-transition period. As Serbia is at the threshold of the third phase, we will rely on a brief analysis of the first two phases of the transition.

Transition creators in the first phase devise and implement price liberalization and market opening, privatize, abolish or substantially reduce the system of state donations and subsidies by enforcing a "hard" budget constraint (Svejnar, 2002). In addition, at this stage, the budget is stabilized and monetary stability is established. As part of creating the basis for the functioning of the market economy, it is also the creation of an adequate social program.

At this phase, the constitution of a new institutional arrangement is starting, in order to allow changes of inherited economic structure as soon as possible. In developed countries, the institutional framework has been built over a long period of time, can be said for centuries, along with the development of the liberal market. Therefore, it was created evolutionarily. Serbia has a completely different situation. Since the beginning of the transition process in post-socialist countries (at the end of the 1980s), Serbia's economy functioned according to rules that more or less deviated from the norms of behavior of developed market economies.

In creating a new physiognomy of market institutions, architects of ecomonic-system solutions in Serbia set the goal defined as building an open market economy. Transition into the market economy is a period of intense reform processes. With the desired macroeconomic stability, it tended to achieve the complex of objectives such as reform of the real and financial sector. Privatization has been highlighted in the last years as a key process. The establishment of a new ownership and management structure in enterprises should have enabled expansion of the entrepreneurial initiative and stable economic development in the long run. In order to 
speed up the reform process, the creators emphasized the unrealistic hope that even in unstable political occasions, favorable environment for foreign investments could be achieved. This primarily refers to the possibility of attracting foreign direct investments that could bring new programs, new technologies, placement of products to foreign markets, new entrepreneurial spirit, creativity and inventiveness. The results, as can be seen from numerous data, are missing. The reason is well known: the inflow of foreign capital depends primarily on the risk of investment and prospects and the certainty of establishing economic stability in the long run with a clear legal system and within that unambiguous legal security of property. The scarce domestic savings and domestic capital from official and gray flows fill gaps at the desired pace of investments, going into secure placements or privatization of the remaining companies. The global crisis in the financial markets has also further complicated capital inflows in Serbia.

There are numerous problems related to the implementation of legal regulation in the functioning of the economy. Changes in the real and financial sectors are, as a rule, much more complex than changes in the monetary sphere. Macroeconomic stability can be established from a single center of power and decision-making (the Government and the Central Bank) using a small number of instruments. On the other hand, recipes for achieving macroeconomic stability are relatively simple, to a great extent universally applicable and implemented on the basis of suggestions, that is, under direct or indirect influence of the International Monetary Fund. The proof for these claims is the fact that all countries in our neighborhood have stable currencies and an enviable level of foreign exchange reserves, although they have different results in changing the economic structure and improving economic performance.

It is much more complex to establish a social environment stimulating for economic subjects. Such an environment must necessarily imply market infrastructure and efficient institutions adapted to the functioning of the economy in new conditions, as well as the motivation system for achieving high business performance. The economic performance of the Serbian economy shows that the results of the delayed transition are relatively modest. Restructuring of the economy can only be partially accomplished by dictation or the prescribing of measures and procedures. Such a procedure is applied selectively in companies that, according to the estimates of economic policy makers, have strategic significance, that employ a large number of employees or, in the perspective, can increase the value of capital. In the case of such enterprises, the state abandons the principle of hard budget constraint. Such an intervention in economic and general social trends can only make sense if: 1) it is time-limited and 2) implemented with the aim that the economy and society can successfully spontaneously operate after it is abolished.

The rest part of the economy is left to solving its, as a rule, accumulated problems, applying to the principle of reliance on its own strengths and a firm budget constraint. A small number of stumbled companies are waiting for the ending of privatization, which has quite unclear and uncertain effects for the employees. The environment in which they operate is distinguished by the still present financial indiscipline, as well as by the nonapplication of some important legal regulations. The debt economy and the negligible size of the gray economy limit even potentially successful companies to achieve better economic results. Despite numerous declarative efforts to stimulate the development of small and medium-sized enterprises, in reality, the effects are very modest. At the same time, a slow restructuring of large systems takes place, so that there is not formation of more flexible forms for organizing business from this specific potential. 


\section{The role of the state in the functioning of institutions and transitional engineering in Serbia}

The creation of the necessary market infrastructure, ie. the institutions of a market economy, with the introduction of the elements of a democratic society, present the basic task of the state in transition. The market is a set of formal and informal rules for matching supply and demand. In addition, by appropriate legal regulations, state clearly define the behavior framework for economic entities, stability in the expression of interests and the achievement the goals. By clearly defining the rules of behavior and space for economic activity, the state affects the relationship between economic actors and the environment, creating the preconditions for achieving the highest level of social well-being.

Since the creation of implementation policy for transition process is in the hands of the state, redefinition of its classical non-economic as well as economic functions is imposed as a necessity. With a clear determination of the state's competences in the field of economic life, it is necessary to re-examine the scope and quality of the participation of the state sector in the creation of domestic product. This is a demand for the withdrawal of the state from the regulation of basic economic flows (deregulation) with the necessary preservation of public functions.

Already in the initial phase of transition, states must establish basic constituent and regulatory principles. The constitutive role of the state consists of securing the openness of the economy, defining ownership rights, guaranteeing the freedom of business entities, managing a consistent economic policy. The regulation function rfers to the introduction and compliance with legal regulations, including the prevention of any monopolization. With these principles a competitive preasure can be achieved. The ways of achieving competitive order are different because combinations of systematic and regulatory mechanisms are different. Every economy should seek for the shortest way to achieve optimal solutions that will ensure the greatest economic and social development in general.

The creators of the transition process in Serbia had a very complex task to design its flow and content. One of the more important tasks is mass and quick privatization. However, it is necessary, but not sufficient condition for an effective transition. In addition to regulating property rights, it is necessary to simultaneously perform other institutional changes. In conceiving the goals and way of transforming the economy, often in theory and practice starts from the norms of a liberal market economy and demands for an integrated market and the universal functioning of the market mechanism with informative, selective, allocative and distribution function. Neoliberalism, as shown by many serious analyzes in developed countries, but also in countries in transition, has a number of defects. In the case of uncritical download the concept of liberal market economy, there are a number of problems that Serbia will try to solve with interventionism more difficult incompare to rich countries.

Building a market infrastructure requires time and can not, except in certain segments, be established by decrees. Also, building an integrated market implies creating a favorable socio-economic environment. Realizing the necessary changes in the economic, system and institutional environment must be consciously controled process. For this reason, this process is a combination of spontaneous and planned guidance with 
greater or less domination and the significance one of these two approaches depending on the phase of transition processes.

Analysts are in a position to evaluate the first two phases of transition in Serbia. The first phase was pure constructivism. Transition designers have devised and implemented price liberalization and market opening, privatized, abolished, or substantially reduced the system of government grants and subsidies by enforcing "hard" budget constraints. In addition, at this stage, a balanced budget and monetary stability have been established. All this was followed by an appropriate social program.

Already at this stage, the establishment of a new institutional arrangement has begun which helped to inherited economic structure change as soon as possible. The costs of building institutional infrastructure were a significant factor for delaying or slowing down its overall constitution. Effective institutions should create a positive difference between benefits and costs associated with restructuring, adaptation or building market relations. The transition does not have an alternative, so it is necessary to complete the process of introducing business-system solutions based on elements of market infrastructure in order to achieve faster economic development and improve the performance of the economy and individual economic entities, together with other relevant influences.

In creating a new physiognomy of market institutions, the creators of economicsystem solutions set building an open market economy as the goal. Transition into the market economy is a period of intense economic reforms. The establishment of a new ownership and management structure in enterprises should enable the expansion of entrepreneurial initiative and stable economic development in the long run. In order to speed up the reform process, favorable environment for foreign investments should be built up, primarily to attract foreign direct investment, which can bring new programs, new technologies, placement of products to foreign markets, new entrepreneurial spirit, creativity and inventiveness. The inflow of foreign capital depends primarily on the political situation in the country and on the establishment of economic stability in the long run with clear legal system and within this unambiguous legal security of property.

The state plays a fundamental role in creating market environment. This role is reflected in the fact that laws and regulations regulate economic space. Thanks to the commitment to fundamental reconstruction of the economy and society, transition in Serbia is in some areas almost at the beginning. If spontaneous building of institutions, which are characteristic of developed market economies, would be realized, the process would require a long period of time. For countries in transition, time is a very scarce factor, so it is the most rational to stimulate a part of the economy whose development, with relatively small investments, will have effects on general economic development.

The critique of the previous transition engineering in Serbia must start from the achievements of alternative transitional projects in other countries, on the one hand, and from the norms of developed market economies, primarily the countries of the European Union, on the other hand. There are numerous limitations for easy copying of foreign experiences. In the process of ownership transformation, Serbia's economy relies on a pure market model (buying and selling companies by public tender or public auction). All this is done in the absence or inconsistent implementation of some important legal norms related to the real and financial sector. Without fully-built market institutions, it is impossible to achieve the intent of the law. 
Economic transition should be achieved with a previously reached consensus on the necessity of radical reform efforts in the economy and society. This primarily refers to the institutions of executive and judicial power. Considering the delay in starting the transition, a clear and unequivocal discontinuity with the previous economic and systemic arrangement is necessary as a prerequisite for a fundamental reconstruction of the economy and society. Completion of privatization and restructuring of public enterprises represent the most significant problems in the years to come. Too big public sector imposes the need and necessity for state withdrawal and the search for alternative owners. Thanks to the party interests and inefficiency of the state, bulky, inert, and corruption-based system of administration and bureaucracy has been created.

The creators of transition in Serbia declaratively declare for fundamental reconstruction of the economy and society. In the period after the October events in 2000 , in a relatively short period of time, partial completion of normative regulations was done with laws and other regulations and rules that should induce positive effects on the functioning of the economy. At the same time, but not always synchronized, harmonization with the legislation of the European Union was made, which is the condition for the accession of our country to the integration flows in Europe. However, in the implementation of these solutions, numerous problems arose. The current situation in Serbia in this area points out serious discrepancy between the desired and actual state of the economy, so it suggests us that there is not radical engagement in the scene, but a reform that, in its basic meaning, has the adjustment, change, but also insufficiently strong termination with recidivists of the past. The reasons for this are most often in the unfulfilled change of institutions and delay in the formation of new mechanisms for the functioning of the economy.

There is a discrepancy between the normative part of the economic system and the real forms and ways of doing business. This indicates the current state of our economy and the results of the business entities. This mismatch between the normative and factual economic system has several causes. The broadest formulation of these causes is the slow and insufficiently comprehensive implementation of laws and commitments to radical change.

\section{Conclusion}

Reform in society involves the creation of institutions that would provide a modern service to the environment. Based on the experiences of the previous transition in Serbia, it turned out that institutions, from the level of local government to the highest state bodies, have not been substantially reformed. Under such conditions, institutions do not represent representatives of business entities and individuals interests. Insufficient dispersion of power has created great, decades back, concentration of power in the possession of small layer of influential centers of power. Only a radical change in the mechanism of govenrment and rule can reduce or eliminate the created system of unnecessary administration and bureaucracy.

In the process of conceiving the transition, it was counted with a significant presence of foreign investors and aid in the donations form. In the previous period, the scarcity of direct investments is concerned, as a result of insufficient interests in 
investing capital in our country. It remains to be seen how, in the absence of investment funds, there will be readiness and courage to maintain macroeconomic stability. The necessity of completing the initiated process is related to the risk of serious violation of social justice and possible, primarily political, consequences resulting from it.

Starting from the performance of our economy and the inefficiency of institutions, critique of the current transition engineering in Serbia can be addressed. The transition recession was created as a result of restructuring the economy and adapting to new business conditions without synchronized institutional changes. There are also numerous 'excursions' into populism. In addition, it seems that a political consensus has been reached on the necessity of radical reform efforts in the economy and in society. Given the delay in starting point for political and economic transition in Serbia, a clear and unequivocal discontinuity with the previous economic and system arrangement is necessary. This is a prerequisite for a fundamental reconstruction of the economy and society. The creators of the transition processes in Serbia should, without the necessity of abandoning strategic commitments, make amendments and corrections in the design or implementation of economic and system solutions in order to eliminate the discrepancy between the norms and the factual situation, thereby preventing the compromising of already achieved results.

\section{Reference}

Đuričin, D. (2007). 'Tranzicija i dostizanje iz perspektive Srbije", Kopaonik biznis forum 2007, Rast institucionalnog kapaciteta i investicionih mogućnosti: glavni izazovi za Srbiju, Savez ekonomista Srbije, Beograd.

Đuričin D. (2006). "Srbija 2012: vizija razvoja i strategija konkurentnosti“, Zbornik radova Kopaonik biznis forum, SES, Beograd.

Đuričin, D. (2008). “Srbija na raskršću: dostizanje EU ili tranzicionizam”, Kopaonik biznis forum, SES, Beograd.

Eucken, W. (1990). Grundsaetze der Wirtschaftspolitik, J.C.B. Mohr, Tuebingen.

Hayek, F.A. (1998). Poredak slobode, Global Book, Novi Sad.

Klaus, V. (1997). Češki put - od realnog socijalizma do slobodnog društva, Odysseus, Beograd.

Stojanović, B. (2007). "Konkurentnost privrede Srbije i politika zaštite konkurencije“, Ekonomika preduzeća, SES, Beograd.

Stojanović, B. (2006). "Zaštita konkurencije u procesu privatizacije“, Ekonomika preduzeća, mart-april.

Svejnar, J. (2002). "Transition Economies: Performance and Chalenges", Journal of Economic Perspectives, 16(1).

Vujačić, I. (1999). "Problemi prirode, tempa i redosleda tranzicije”, Ekonomska misao, br. 3-4. 